\title{
In defence of genital autonomy for children
}

\author{
Brian D Earp
}

\begin{abstract}
Arora and Jacobs (2016) assume that liberal societies should tolerate non-therapeutic infant male circumcision, and argue that it follows from this that they should similarly tolerate-or even encourage - what the authors regard as 'de minimis' forms of female genital mutilation (as defined by the World Health Organization). In this commentary, I argue that many serious problems would be likely to follow from a policy of increased tolerance for female genital mutilation, and that it may therefore be time to consider a less tolerant attitude toward nontherapeutic infant male circumcision. Ultimately, I suggest that children of whatever sex or gender should be free from having healthy parts of their most intimate sexual organs either damaged or removed, before they can understand what is at stake in such an intervention and agree to it themselves.
\end{abstract}

\section{INTRODUCTION}

In their target article, Arora and Jacobs ${ }^{1}$ contend, among other things, that if nontherapeutic infant male circumcision should be widely tolerated, then so should some forms of what the WHO calls 'female genital mutilation' (or FGM). ${ }^{2}$ i Indeed, there are numerous substantial overlaps, both physical and symbolic, between these two types of genital alteration that are not very widely appreciated; $;^{3-10}$ accordingly, I have prepared an online supplementary appendix ${ }^{\mathrm{ii}}$ in which I outline some of the main morally relevant features that they share. For now, however, let us consider only the conditional argument put forward by the authors, namely that: 'a liberal society that tolerates expression of culture and/or religion in the manner of male circumcision should also permit certain de minimis [female genital altering] procedures'. ${ }^{1}$

I offer a different perspective. Rather than proceeding from the premise that non-therapeutic, non-consensual male genital alteration (MGA) is clearly

${ }^{\mathrm{i}}$ The terminology here is notoriously contentious: see, for example, Davis ${ }^{3}$ for an in-depth discussion. I will simply follow Arora and Jacobs in using 'female genital alteration' (FGA) for the remainder of this essay.

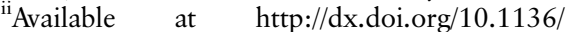
medethics-2015-103030. Please note that this appendix also includes a more detailed response to many of Arora and Jacobs's more problematic claims, focusing on those that I did not have the room to address in the main text of this commentary.

Correspondence to Brian D Earp, Visiting Scholar, The Hastings Center Bioethics Research Institute, Garrison, NY, 10524, USA; brian.earp@gmail.com permissible (and should therefore be widely tolerated in liberal societies) to the conclusion that purportedly 'de minimis' forms of non-therapeutic, non-consensual female genital alteration (FGA) should also be permitted, I will instead move in the opposite direction. My strategy will be to highlight some of the downsides that seem likely to follow from an increased tolerance for FGA in Western societies, and use this as a premise from which to argue that it may be time to consider a less tolerant position towards MGA. Please note that I will not be arguing in favour of a 'ban' on MGA (for reasons I go into elsewhere $)^{11-13}$ but rather for its being strongly discouraged, perhaps through some form of regulation (akin to the proposal by Ben-Yami in an earlier issue of this journal). ${ }^{14}$

\section{SOME PROBLEMS WITH INCREASING TOLERANCE FOR FGA IN WESTERN SOCIETIES}

Here are some problems that seem likely to follow from a more tolerant position towards FGA.

\section{Legal problems}

FGA, including its 'minor' forms, is currently illegal in the vast majority of liberal societies (I will focus on so-called Western countries, such as the USA, Canada, Australia and the countries of Europe). ${ }^{15} 16$ To change this situation, at least according to one plausible interpretation, it would require that the laws regarding physical assault on a minor be rewritten, potentially creating widespread disturbances and inconsistencies throughout their respective legal systems. This is because, as some scholars have argued, cutting into a child's genitals without a medical diagnosis, and without its informed consent, meets the formal definition of criminal assault under the legal codes of most of these societies. ${ }^{4}$ 17-20 (Please note that this view assumes that parental 'proxy' consent is invalid for such procedures, for which arguments have been given elsewhere.) ${ }^{20-22}$ Indeed, in its move to ban FGA in 1997, the US Congress stated 'that it 'infringes upon the guarantees of rights secured by Federal and State law, both statutory and constitutional'. That is to say, [non-therapeutic] female genital cutting [without consent] was already unlawful' prior to the enactment of specific legislation. ${ }^{23}$

A further issue, as Blackstone noted more than 200 years ago, is that 'the law cannot draw [a] line between different degrees of violence ${ }^{24}$ [p. 270]. What this means is that if any particular act of violence-such as the cutting of a child's body in the absence of medical necessity, perhaps especially with the effect of damaging or removing functional tissue-is legally permitted, then fraught decisions have to be made 'as to where within the continuum of violence the limits are to be fixed $^{25}$ [p. 129]. This, in turn, could open the door for interested parties to argue, for any proposed act of cutting, that it is not 'violent enough' to warrant the placement of limitations on parental decision making. ${ }^{4}$ More on this will be said in a subsequent section.

An additional problem is that changing the law would remove at least one important tool that reformers from within the affected communities can appeal to, in their quest to end the spectrum of FGA practices. Specifically, many women from established immigrant groups report that they do not wish to continue subjecting their daughters to FGA (for an excellent review of the evidence concerning 'cultural change after migration' with respect to this issue, see the work of Johnsdotter and Essén $)^{26}$ but they may face pressure from fellow group members. ${ }^{27}$ This can make it difficult for any one parent or family to unilaterally challenge, much less abandon, the tradition: as Mackie has argued, it is a collective action problem. $^{28} 29$ What a legal prohibition allows, then, is for reformers from within these groups to be able to point to the law and say, 'I have no choice but to keep my daughter's genitals intact', effectively resolving the social dilemma. ${ }^{27} 30$

Finally, as Ludbrook argues, 'the law is an important symbol and if [it] allows parents, carers and teachers to [so much as hit their] children', much less cut into a physically and symbolically sensitive part 
of their bodies, 'it is sending a message to these people and to the community generally that children are not entitled to the same right to bodily integrity as adults ${ }^{25}$ [p. 129].

Against this view, Arora and Jacobs argue that (what they regard as) 'de minimis' forms of FGA 'do not constitute a human rights violation' with respect to bodily integrity, because they have 'no more effect than other accepted procedures performed on minors for esthetic enhancement'. ${ }^{1}$ In previous writings, they have listed mole removal and cosmetic orthodontia as examples of such procedures. ${ }^{31}$ But as I have suggested elsewhere:

\begin{abstract}
'the genitals (in particular) might plausibly be seen as having a special, even unique psychosexual significance compared to other parts of the body, which could make their un-consented alteration more likely to be experienced (later on) as a harm. [This] could help to explain why there is an active 'genital autonomy' movement in the United States, Europe, and elsewhere-fueled by women, men, and intersex people who are extremely resentful about their childhood genital surgeries-but not an anti-orthodontics movement or an antimole removal movement ${ }^{32}$ [p. 45].
\end{abstract}

More could be said about this disagreement. For a thoughtful analysis of the right to bodily integrity as it applies to preautonomous individuals, see the essay by Ungar-Sargon in a recent issue of this journal. ${ }^{33}$ See also the work of Darby on a child's 'right to an open future. ${ }^{34}$ For an extended articulation of my own views concerning the ethics of ostensible 'enhancement' procedures in children, see the references here. ${ }^{5} 123536$ iii

\section{Regulatory problems}

Another problem with the authors' proposal has to do with monitoring and regulation. As Arora and Jacobs concede, their suggestion might 'open the door' for 'more invasive procedures [to be carried out] under the guise of de minimis procedures' ${ }^{1}$ thereby increasing the overall level of harm. In response to a similar policy proposal by the American Academy of Pediatrics (AAP) in 2010 (see later discussion), the Somali-born writer and

iii Of particular relevance is the essay, 'Between Moral Relativism and Moral Hypocrisy: Reframing the Debate on 'FGM',' in press at the Kennedy Institute of Ethics Journal. The accepted manuscript is available online ahead of print here: https://www.academia.edu/10197 867/Between_moral_relativism_and_moral_hypo crisy_Reframing_the_debate_on_FGM_. activist Hirsi Ali asked: 'how could we tell that parents who want to ensure that their daughter will be a virgin on her wedding night will not have her (legally) nicked [on one day] and then a few months later (illegally) infibulated? ${ }^{37}$ Indeed, as Leye and colleagues point out, 'in some communities, traditional circumcisers will 'redo' girls if they notice that only an incision has been made ${ }^{38}$ [p. 368].

The authors' response to this type of objection is that 'given the widespread nature currently' of the more invasive procedures, 'if even a few girls undergo a de minimis procedure instead of a more invasive one due to this strategy then the strategy is appropriate'. ${ }^{1}$ However, they do not provide any evidence that the more invasive procedures are in fact 'widespread' in Western countries, specifically, which is the legal setting most relevant to their arguments (and readership); in fact the recent survey by Johnsdotter and Essén stands in direct contrast with this scenario. ${ }^{26}$ Moreover, if permitting 'minor' forms of FGA actually had the effect of lending a 'cloak of respectability' to all FGA procedures-a possibility that Arora and Jacobs themselves raise, but do not adequately consider-then the more invasive forms might very well increase in number, leading (again) to greater harm overall. Since the authors do not provide any persuasive evidence in favour of their own predicted outcome as opposed to this plausible alternative, it is unclear why we should endorse their policy proposal, even on consequentialist grounds.

A related problem is more practical in nature. How would the actual cutting sessions be monitored (and by whom) to make sure that only the 'right amount' of tissue was being incised, damaged, or removed? Arora and Jacobs admit that this is a problem with their proposal. But instead of addressing it, they simply divert attention to other problematic practices. As they write: 'The concern regarding amount of tissue being removed is ... not unique to FGA, but is similar to male circumcision as well as cosmetic surgeries on adults'. ${ }^{1}$

They are right to raise the example of male circumcision. At least one underdocumented risk of this procedure, especially when carried out in infancy, is the removal of too much tissue-sometimes causing painful erections when the child grows up. ${ }^{39-42}$ To put it simply, there is no 'dotted line' showing where to cut around an infant's diminutive penis, just as there is no determinate location where the foreskin ends and where the rest of the penis begins. This uncertainty in terms of where to cut, and the associated risk of cutting away too much, arguably speaks in favour of deferring the surgery until the organ has reached its full size. Then, the individual whose genital integrity is at stake can indicate exactly how much tissue - if any $-^{\mathrm{iv}}$ he would like to have removed, and he can do so under conditions of informed consent.

A similar analysis applies to FGA procedures. In fact, this parallel leads us directly to the other diversion mentioned by the authors, namely, 'cosmetic surgeries on adults'. The key word is 'adults'. If an adult female wishes to undergo a genital surgery (to choose the most pertinent example) for cosmetic, cultural, religious or other reasons, there is indeed, as Arora and Jacobs point out, a non-trivial risk that too much tissue will be removed, or that the surgery will yield unsatisfactory results in any number of other ways. But this would be mitigated by the fact that the surgery was undertaken voluntarily. In other words, the primary (moral) difference between consensual genital surgery, and both FGA and MGA carried out on children, is that an adult can assess the relevant risks in light of her own goals and values, and determine whether they are 'worth it' to her, all things considered. ${ }^{35}{ }^{43}$ A child has no such recourse.

Speaking generally, then, the suggestion of harm tolerance when it comes to interventions into children's bodies is untenable. In part, this is due to 'the difficulty it presents in terms of specifying an appropriate threshold for harm that could be measured in an objective way ${ }^{4}$ [p. 98]. As Van Howe notes, the meaning of 'harm', in practice, therefore, will inevitably be left up to the interpretational vagaries of each provider, perhaps in consultation with the child's parents. ${ }^{44}$ This vagueness creates a problem: 'there are practitioners, especially in cultures where female circumcision is common, who fervently believe that more invasive forms of female circumcision'-that is, forms that even Arora and Jacobs reject-'do not pose risks of physical or psychological harm $^{, 44}$ [p. 167]. In fact, these providers could easily make selective appeals to studies from the medical literature that appear to show health-based benefits for FGA, ${ }^{4}$ as well as an absence of serious harms, ${ }^{45}$ much as some supporters of MGA are prone to do. ${ }^{46}{ }^{47}$ When the

\footnotetext{
${ }^{\text {iv }}$ The overwhelming majority of men who grow up with intact genitalia do not go on to pursue circumcision later.
} 
many purported cultural benefits of FGA are factored in, Van Howe continues, 'practitioners could easily convince themselves that any harm is more than offset by the many perceived benefits ${ }^{44}$ [p. 167].

\section{Medical problems}

Potential problems concerning clinical and surgical matters have been raised by Leye and colleagues. They write: 'it is difficult to avoid damaging the clitoris when performing a ['de minimis'] incision, especially in genitalia that are not fully developed'. Moreover, 'complications (such as shock, infections, sepsis, and bleeding) are difficult to avoid [entirely], even with [such a minor] incision, 38 [p. 368]. Thus, as Goldman has stated, the assumption that 'de minimis' interventions into a child's vulva really are essentially harmless is 'debatable'. As he goes on to write: even if it could be shown that the harm is, in some sense, 'relatively minor, it is still harm. Certainly, there is physical harm or risk of physical harm any time a cutting instrument contacts sensitive genital tissue'. ${ }^{48} \mathrm{He}$ concludes, then, that the 'burden of proof' is on those who argue that the risk of harm is trivial.

How Arora and Jacobs could meet this burden is unclear. First, as they note, it is currently illegal in Western societies to perform FGA procedures in children, so it is impossible to collect the very data that would be needed to make their case. But let us just assume that the ban were lifted. How long would it be reasonable to allow for such procedures to be performed in the absence of high-quality long-term follow-up data (concerning such vital issues as the effects of these procedures on, eg, sexual function, sensation and satisfaction) before it became possible to show that they had, in fact, been more harmful than Arora and Jacobs guessed that they would be?

An example should elucidate the danger. Consider 'procedures resembling elective labiaplasty as performed in Western nations', which Arora and Jacobs use to illustrate category 2 of their proposed typology. This refers to interventions that 'create morphological changes, but are not expected to have an adverse effect on reproduction or on the sexual satisfaction of the woman or her partner'. ${ }^{1}$

Arora and Jacobs argue that such procedures should be considered permissible in young girls, so long as they are requested by the parents. Problematically, however, the only available studies assessing reproductive and sexual outcomes associated with this particular intervention stem from surgeries performed on consenting adult women (or older adolescents); and even then the data are woefully incomplete. ${ }^{49}$ But-again-let us just assume that, one day, researchers do produce a robust and convincing benefit-to-risk (or benefit-to-harm) ${ }^{50}$ profile for non-therapeutic labiaplasty or similar procedures carried out on adults. Even so, we could not be sure that the profile would apply to children. ${ }^{32}$ For one thing, sexual outcomes, in particular, are highly subjective; ${ }^{51}$ and the women who undergo procedures akin to labiaplasty and subsequently report on their effects are unlikely to be representative of the general female population. This is because, overwhelmingly, they will have pursued their elective genital surgeries precisely because they were unsatisfied with their labia/vulva in some way, and wanted a change. In the case of a young girl, however, we cannot know, in advance, how she will (later) regard her own vulva-she might value her genitals in their intact state very highly-and so we are not in a position to judge how their modification would affect her sexual experience.

\section{Sexual problems}

Against this view, it might be argued that if genital tissue is excised early enough, a girl will not 'know what she is missing' when she reaches an older age. Similar arguments are raised in support of performing male circumcision as early as possible. But this does not guarantee a 'harmless' outcome. On the contrary, such an intervention could just as easily lead to feelings of loss or resentment-whether or not the surgery itself was consciously remembered. After all, a woman might reasonably wonder what sex, masturbation, and so on would have been like had her vulva been left intact, and feel angry that she was not given the chance to find out. In line with this perspective, there are indeed many documented reports of women (as well as men and intersex people) who had their genitals modified for non-therapeutic reasons in early childhood, who do in fact experience anger and resentment. These feelings, in turn, have the potential to impact negatively on sexual experience, quite apart from any 'purely' physical effects that would ensue from the loss of sensitive tissue (see Box 1). $222752-56$

The lesson here is that classification of childhood genital surgeries based on 'predicted' effects on sexuality is a mistake.
Box 1 What are the likely effects of procedures resembling labiaplasty on a woman's sexual experience?

As Runacres and Wood note, 'the labia minora are highly innervated along the entire free edge, and are involved in the process of engorgement during sexual arousal. It follows therefore that labiaplasty has the potential to remove tissue that contributes to sensory sexual arousal'. In fact, 'the labia minora are second only to the clitoris for both sensation and sensitivity and are more sensitive than the vaginal introitus' ${ }^{49}$ In addition, the labia can be orally and manually manipulated, which may yield particular sensations that would be physiologically impossible if the tissue were removed - an outcome that Arora and Jacobs seem to regard as irrelevant. Whether such an outcome is on balance negative, of course, cannot be 'scientifically' determined; rather, it depends on an individual's sexual preferences. For example, for those for whom the ability to fondle, etc., the labia is an important part of their sexual activity, the surgical reduction or elimination of this tissue would indeed be expected to 'have an adverse effect on ... sexual satisfaction'. The upshot is that everyone is different. Thus, as Johnsdotter has argued, there is no consistent relationship between type or degree of genital cutting - whether in females, males or intersex people-and subjective sexual pleasure later on. Hence: 'the current academic focus on the role of genitalia in understanding sexual pleasure is a dead end. While genitalia usually are central to sexual activity, and can be seen as a prerequisite for sexual intercourse, it is a misapprehension to see the state of them (cut or uncut) as determinative of the individual's experience of the sexual encounter. Consequently, ongoing debates on enhancing or detrimental effects of circumcision practices often miss the point, since they are based in too narrow a theoretical framework of sexual pleasure ${ }^{59}$ [p. 262]. See the online supplementary appendix for further discussion: http://dx.doi.org/10. 1136/ medethics-2015-103030.

Since everyone's genitals are unique (including the specific distribution of nerve endings, how sensitive the tissue is in different parts, and so on), and since 
people have different attitudes towards intact versus modified genitals, as well as different sexual preferences that can range rather widely, it is not ethically useful to make bland, medicalised statements about expected sexual satisfaction considered as an 'average' effect of some intervention. This is especially the case given that such an outcome is typically measured by reductive 'scientific' surveys involving numbered scales or similar, often failing to control for socially desirable responding. ${ }^{32} 57$

Indeed, Arora and Jacobs's willingness to rely on such statements in their endorsement of both male ${ }^{31}$ and female ${ }^{1}$ forms of non-therapeutic genital alteration, rather than proceeding cautiously and recognising the limitations-or even nonexistence- of the pertinent data, ${ }^{32}$ is worrying. When a child's genitals are on the line, along with the prospect of diminishing his or her future sexual function and/or satisfaction (the latter of which is a highly subjective notion), we should be extremely careful about making assumptions of no harm when the available data are so weak and contentious.

\section{Cultural problems}

A further problem is that Arora and Jacobs's proposal is culturally incoherent. On the one hand, they decry 'culturally insensitive' laws and language that seek to eliminate female genital 'mutilation'. But on the other hand, they offer a made-up, 'medicalised' ritual of their own design, without explaining how this would satisfy the real-life cultural impulses of the families who endorse FGA. As they themselves state, "We are ... not suggesting that people whose beliefs or sense of propriety leads them to perform these procedures on their children would necessarily accept alterations to their practices to conform to the authors' views of what is acceptable'. ${ }^{1}$ Indeed-why would they? As Hirsi Ali has written: 'To understand this problem, we need to begin with parental motives. The 'nicking' option is regarded as a necessary cleansing ritual ... the clitoris is considered to be an impure part of the girl-child and bleeding it is believed to make her pure and free of evil spirits'. Problematically, however, for girls in at least some communities, the point of FGA is 'to ensure their virginity ... and to curb their libido to guarantee sexual fidelity after marriage'. Thus, when FGA is intended 'to ensure chastity before marriage and to curb female libido ... the nick option [would not be] sufficient' from a cultural perspective. ${ }^{37}$

\section{Political problems}

Finally, there is almost no chance that Arora and Jacobs's suggestion will actually be taken up by lawmakers: it is a political non-starter. This can be inferred from the debacle that ensued in 2010, when the AAP issued a policy similar to the one proposed by the authors, in the name of 'cultural sensitivity'. As Arora and Jacobs discuss, it was summarily retracted (just 1 month later) after it was met with fierce opposition and even outrage. ${ }^{58}$ Opponents of the AAP policy included survivors of FGA such as Ayaan Hirsi $\mathrm{Ali}^{37}$ and Soraya Mire $;^{58-60}$ members of its own ranks; ${ }^{44} 6162$ distinguished doctors from other countries; ${ }^{63}$ US lawmakers; ${ }^{64}$ and organisations such as Equality Now, an international advocacy network fighting to end female genital cutting. ${ }^{65}$ v In fact, I expect that Arora and Jacobs's own proposal (as well as perhaps the Journal of Medical Ethics, for publishing it) will be met with a similar outcry. While their article constitutes an interesting (if unoriginal $)^{3}$ academic exercise, Western societies have, for the most part, reached the seemingly irreversible conclusion that sharp objects should not be taken to the vulvas of little girls, unless it is to save their life or health. ${ }^{11}$ Importantly, many immigrant communities in these same societies-derived from populations where FGA has traditionally been performed-have reached the same conclusion, and have willingly given up the practice. ${ }^{26}$ It would be sobering for those who have struggled towards this end to see such progress reversed.

There are numerous other problems with Arora and Jacobs's proposal, including misleading (or inaccurate) citations concerning key empirical assertions, but I do not have the space to cover them all in detail in this response. Instead, I refer the reader once again to the online supplementary appendix accompanying this

${ }^{\mathrm{v}}$ Similar patterns have played out in other countries. For example, as Leye $e t a l^{38}$ [p. 367] report (internal references omitted): 'In 1992, two researchers in the Netherlands submitted a report to the Dutch Ministry of Health in which they proposed that as a step toward the total eradication of the practice, incisions of the clitoris be allowed in cases where the parents or family wanted to circumcise a girl. This kind of incision was considered as a nonmutilating form of 'female circumcision', as FGM is commonly referred to in the Netherlands. This report's recommendation provoked a public debate about the issue that resulted in the total rejection of any form of FGM and, moreover, the rejection of any attempts to differentiate between mutilating and nonmutilating forms of "female circumcision". article, in which I discuss these and other matters (see http://dx.doi.org/10.1136/ medethics-2015-103030).

\section{CONCLUSION}

In summary, if Western societies were to change their laws in order to allow for more 'minor' forms of FGA, this would likely result in: (a) disturbances and inconsistencies throughout their legal systems, possibly requiring new definitions of bodily assault and opening the door for inadvertent legal protection of a wide range of potentially harmful practices (typically carried out on children, who cannot adequately defend themselves); (b) removal of an important tool that reformers from within the affected communities rely on to solve the 'collective action' problem introduced by FGA; (c) regulatory challenges in tracking and monitoring FGA cutting sessions to ensure that they were not being used as opportunities for more invasive procedures; (d) exposure of young girls to an unknown amount of surgical risk in the absence of medical need, thereby placing doctors in an untenable position with respect to their professional duties; (e) accusations of cultural insensitivity, on account of outsiders having invented a 'compromise' intervention to be carried out in a medicalised setting, with the aim of replacing the traditional rituals that carry meaning for the relevant communities; and (f) widespread outrage among women who consider themselves victims and/or survivors of FGA as well as their allies, and other forms of political backlash.

In light of these considerations, let us return to Arora and Jacobs's major conditional argument, namely, that 'a liberal society that tolerates expression of culture and/or religion in the manner of male circumcision should also permit certain de minimis [female genital altering] procedures'. ${ }^{1}$ I have tried to show that such permissiveness would result in a fiasco, making this suggestion (for all intents and purposes) a reductio ad absurdum. Accordingly, there is a growing trend among scholars of genital cutting, particularly in the fields of bioethics and law, of arguing that it is time to consider a less lenient position towards MGA (whether by banning it with a possible exception for sincere religious belief, or by regulating it in other ways), rather than a more lenient position towards FGA. ${ }^{8} 91743$ 66-68 As Arora and Jacobs themselves point out,

'We acknowledge that issues of cultural sensitivity and gender discrimination in 
the disparate treatment of male circumcision and FGA could also be treated by proscribing both, instead of the position for which we are advocating. In fact, many have criticised male circumcision as a human rights violation due to the lack of autonomous decision-making and the irreversible nature of the procedure'. ${ }^{1}$

Whether it is in fact a fundamental human rights violation, or rather a morally objectionable practice on other grounds, 'it is clear that the current laissez faire attitude towards MGA that is typical of Western societies-and in particular the United States-can no longer be maintained without facing serious scrutiny. FGA and MGA are both highly problematic practices, with far more overlap between them (both physically and symbolically) than is commonly understood: they should not be discussed, therefore, in hermetically sealed moral discourses'. My own perspective is that the most promising way forward would be to argue for an 'autonomy-based' ethical framework, ${ }^{49}$ whereby 'Children of whatever [sex or] gender should not have healthy parts of their most intimate sexual organs removed, before such a time as they can understand what is at stake in such a surgery and agree to it themselves'. ${ }^{69}$

Acknowledgements Thanks are due to Mikey Dunn for constructive feedback on an earlier draft of this response.

\section{Competing interests None declared.}

Provenance and peer review Commissioned; internally peer reviewed.

- Additional material is published online only. To view, please visit the journal online (http://dx.doi.org/ 10.1136/medethics-2015-103030).

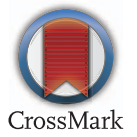

To cite Earp BD. J Med Ethics 2016;42:158-163.

Received 27 November 2015

Accepted 2 December 2015

Published Online First 20 January 2016

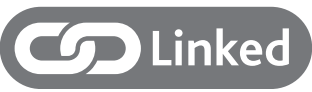

- http://dx.doi.org/10.1136/medethics-2014-102375

- http://dx.doi.org/10.1136/medethics-2015-103027

- http://dx.doi.org/10.1136/medethics-2015-103029

- http://dx.doi.org/10.1136/medethics-2016-103376

J Med Ethics 2016;42:158-163.

doi:10.1136/medethics-2015-103030

\section{REFERENCES}

1 Arora $\mathrm{K}$, Jacobs A. Female genital alteration: a compromise solution. J Med Ethics 2016;42:148-54.
2 WHO. Classification of female genital mutilation. (cited 12 Nov 2015). http://www.who.int/ reproductivehealth/topics/fgm/overview/en/

3 Davis DS. Male and female genital alteration: a collision course with the law? Health Matrix 2001:11:487-570.

4 Earp BD. Female genital mutilation and male circumcision: toward an autonomy-based ethical framework. Medicol Bioethics 2015;5:89-104.

5 Earp BD. Between moral relativism and moral hypocrisy: reframing the debate on "FGM." Kennedy Inst Ethics J 2016 (in press). https://www.academia. edu/10197867/Between_moral_relativism and moral_hypocrisy_Reframing_the_debate_on_FGM_

6 Svoboda JS, Darby R. A rose by any other name? Symmetry and asymmetry in male and female genital cutting. In: Zabus C, ed. Fearful symmetries: essays and testimonies around excision and circumcision. Amsterdam and New York: Rodopi, 2008:251-302.

7 Caldwell JC, Orubuloye IO, Caldwell P. Male and female circumcision in Africa from a regional to a specific Nigerian examination. Soc Sci Med 1997:44:1181-93.

8 DeLaet $\mathrm{DL}$. Framing male circumcision as a human rights issue? Contributions to the debate over the universality of human rights. J Hum Rights 2009;8:405-26.

9 Svoboda JS. Promoting genital autonomy by exploring commonalities between male, female, intersex, and cosmetic female genital cutting. Global Discourse 2013;3:237-55.

10 Earp BD. Do the benefits of male circumcision outweigh the risks? A critique of the proposed CDC guidelines. Front Pediatr 2015;3:1-6.

11 Earp BD. The ethics of infant male circumcision. J Med Ethics 2013;39:418-20.

12 Earp BD. Things I've learned (so far) about how to do practical ethics. Practical Ethics 2014. http://blog. practicalethics.ox.ac.uk/2014/03/things-ive-learnedso-far-about-how-to-do-practical-ethics/

13 Waldeck S. Using circumcision to understand social norms as multipliers. Univ Cincinnati Law Rev 2003;72:455-526. http://www.cirp.org/library/legal/ USA/waldeck1/

14 Ben-Yami H. Circumcision: what should be done? J Med Ethics 2013;39:459-62.

15 Krása K. Human rights for women: the ethical and legal discussion about female genital mutilation in Germany in comparison with other Western European countries. Med Health Care Philos 2010;13:269-78.

16 Rahman A, Toubia N. Female genital mutilation: a practical guide to worldwide laws and policies. London: Zed Books, 2000.

17 Merkel R, Putzke H. After Cologne: male circumcision and the law. Parental right, religious liberty or criminal assault? J Med Ethics 2013;39:444-9.

18 Boyle GJ, Svoboda JS, Price CP, et al. Circumcision of healthy boys: criminal assault? J Law Med 2000;7:301-10. http://epublications.bond.edu.au/cgi/ viewcontent.cgi? params=/context/hss_pubs/article/ 1121/type/native/\&path_info=

19 Chegwidden J. The assault we ignore. Children's Rights in Europe: Recent Developments. 17 Sept 2013. https://vimeo.com/78999394

20 Svoboda JS, Van Howe RS, Dwyer JG. Informed consent for neonatal male circumcision: an ethical and legal conundrum. J Contemp Health Law Policy 2000;17:61-133.

21 Adler P. Is circumcision legal? Richmond J Law Public Interest 2013;XVI(iii):439-83.

22 Ford K. "First, Do No Harm": the fiction of legal parental consent to genital-normalizing surgery on intersexed infants. Yale Law Policy Rev 2001;19:469-88

23 Svoboda JS, Adler P, Van Howe RS. Circumcision is unethical and unlawful. J Law Med Ethics (in press).
24 Blackstone W. The commentaries of Sir William Blackstone, Knight, on the Laws and Constitution of England. 1796 edn. Chicago, Illinois: ABA Publishing, 2009

25 Ludbrook R. The child's right to bodily integrity. Curr Issues Crim Justice 1995;7:123-32. http://heinonline. org/HOL/Page?handle=hein.journals/ cicj7\&div $=23 \& \mathrm{~g}$ sent $=1 \&$ collection $=$ journals

26 Johnsdotter S, Essén B. Cultural change after migration: circumcision of girls in Western migrant communities. Best Pract Res Clin Obstet Gynaecol 2015 (in press):http://www.sciencedirect.com/science/ article/pii/S1521693415001959

27 Norman K, Hemmings J, Hussein E, et al. FGM is always with us: experiences, perceptions, and beliefs of women affected by female genital mutilation in London. Options Consultancy Services and FORWARD, 2009. http://www.forwarduk.org.uk/563/

28 Mackie G. Ending footbinding and infibulation: a convention account. Am Sociol Rev 1996;61:999-1017.

29 Mackie G. Female genital cutting: the beginning of the end. In: Female "Circumcision" in Africa: Culture, Controversy and Change. Boulder, CO: Lynne Reinner Publishers, 2000:253-82.

30 Everett JA, Earp BD. A tragedy of the (academic) commons: interpreting the replication crisis in psychology as a social dilemma for early-career researchers. Front Psychol 2015;6:1-4.

31 Jacobs AJ, Arora KS. Ritual male infant circumcision and human rights. Am J Bioeth 2015;15:30-9.

32 Earp BD. Sex and circumcision. Am J Bioeth 2015;15:43-5

33 Ungar-Sargon E. On the impermissibility of infant male circumcision: a response to Mazor (2013). J Med Ethics 2015;41:186-90.

34 Darby RJ. The child's right to an open future: is the principle applicable to non-therapeutic circumcision? $J$ Med Ethics 2013;39:463-8.

35 Carmack A, Notini L, Earp BD. Should surgery for hypospadias be performed before an age of consent? J Sex Res 2015 (in press). http://www.tandfonline. com/doi/full/10.1080/00224499.2015.1066745.

36 Maslen H, Earp BD, Cohen Kadosh R, et al. Brain stimulation for treatment and enhancement in children: an ethical analysis. Front Hum Neurosci 2014;8:1-5

37 Hirsi Ali A. Why are American doctors mutilating girls? The Daily Beast, 2010. http://www. thedailybeast.com/articles/2010/05/20/ayaan-hirsiali-on-injustice-of-female-genital-mutilation.html

38 Leye $E$, Powell RA, Nienhuis $G$, et al. Health care in Europe for women with genital mutilation. Health Care Women Int 2006;27:362-78.

39 Williams N, Kapila L. Complications of circumcision. Br J Surg 1993;80:1231-6.

40 Krill AJ, Palmer LS, Palmer JS. Complications of circumcision. Scientific World J 2011;11:2458-68. http://www.ncbi.nlm.nih.gov/pmc/articles/ PMC3253617/

41 Baskin L, Canning D, Snyder H, et al. Treating complications of circumcision. Pediatr Emerg Care 1996;12:62-8

42 American Academy of Pediatrics Task Force on Circumcision. Male circumcision. Pediatrics 2012;130:e756-85.

43 Dustin M. Female genital mutilation/cutting in the UK: challenging the inconsistencies. Eur J Womens Stud 2010;17:7-23.

44 Van Howe RS. The American Academy of Pediatrics and female genital cutting: when national organizations are guided by personal agendas. Ethics Med 2011:27:165-74.

45 Catania L, Abdulcadir O, Puppo V, et al. Pleasure and orgasm in women with Female Genital Mutilation/Cutting (FGM/C). J Sex Med 2007; 4:1666-78.

46 Donovan B. Review of "In Favour of Circumcision" by Brian Morris. Venereology 1999;12:68-9. 
47 Earp BD, Darby R. Does science support infant circumcision? The Skeptic 2015;25:23-30. https:// www.researchgate.net/publication/269899744 Does_science_support_infant_circumcision

48 Goldman R. Cultural bias may contribute to flawed policy. Pediatrics 2010;125. http://pediatrics. aappublications.org/content/125/5/1088.comments\# cultural-bias-may-contribute-to-flawed-policy

49 Runacres SA, Wood PL. Cosmetic labiaplasty in an adolescent population. J Pediatr Adolesc Gynecol 2015 (in press). http://www.ncbi.nlm.nih.gov/ pubmed/26453828

50 Darby R. Risks, benefits, complications and harms: neglected factors in the current debate on nontherapeutic circumcision. Kennedy Inst Ethics J 2015;25:1-34

51 Johnsdotter S. Discourses on sexual pleasure after genital modifications: the fallacy of genital determinism (a response to J. Steven Svoboda) Global Discourse 2013;3:256-65.

52 Darby R, Cox L. Objections of a sentimental character: the subjective dimensions of foreskin loss. In: Zabus C, ed. Fearful symmetries: essays and testimonies around excision and circumcision. Amsterdam and New York: Rodopi, 2009: 0145-68.

53 Watson L. Unspeakable mutilations: circumcised men speak out. New Zealand: Amazon Media, 2014.

54 Bossio J. Examining sexual correlates of neonatal male circumcision. Doctoral dissertation, 2015 https://qspace.library.queensu.ca/handle/1974/13627
55 Foldès $P$, Cuzin $B$, Andro A. Reconstructive surgery after female genital mutilation: a prospective cohort study. Lancet 2012;380:134-41.

56 Dreger A. Galileo's middle finger: heretics, activists, and the search for justice in science. New York: Penguin Press, 2015.

57 Earp BD. The need to control for socially desirable responding in studies on the sexual effects of male circumcision. PLOS ONE 2015:10:1-12. https://www.researchgate.net/ publication/281976691_The_need_to_control_for_ socially_desirable_responding_in_studies_on_the_ sexual_effects_of_male_circumcision?ev=pub_ cit_inc

58 Chen S. Pediatricians now reject all female genital cutting. 2010 [cited 24 Nov 2015]. http://edition. cnn.com/2010/HEALTH/05/27/AAP.retracts.female. genital.cutting/

59 Pollack M. Circumcision: gender and power. In: Denniston G, Hodges F, Milos M, eds. Genital cutting: protecting children from medical, cultural, and religious infringements. Dordrecht: Springer Netherlands, 2013:297-305.

60 Mire S. The girl with three legs: a memoir. Chicago: Chicago Review Press, 2011.

61 Strandjord S. Opportunity for education plus protection of minors. Pediatrics 2010;125. http:// pediatrics.aappublications.org/content/125/5/1088. comments\#opportunity-for-education-plus-protectionof-minors

62 Bamzai A. Re: AAP response to eletters. Pediatrics 2010;125: http://pediatrics.aappublications.org/ content/125/5/1088.comments\#re-aap-responseto-eletters

63 Bewley S. Sincerity, retraction and apology? Pediatrics 2010;125. http://pediatrics.aappublications.org/ content/125/5/1088.short/reply\#pediatrics_el_50347

64 Luscombe B. Female genital cutting: will US doctors approve nicks? Time 2010. http://content.time.com/ time/health/article/0,8599,1988434,00.html

65 Equality Now. American Academy Of Pediatrics (AAP) is advocating for US pediatricians to perform certain types of Female Genital Mutilation (FGM). Equality Now. 2010 (cited 24 Nov 2015). http://www. equalitynow.org/american-academy-pediatrics-aapadvocating-us-pediatricians-perform-certain-typesfemale-genital-mut

66 Fox M, Thomson M. Short changed? The law and ethics of male circumcision. Int J Child Rights 2005;13:161-81.

67 Tasmania Law Reform Institute. Non-therapeutic male circumcision, 2012. http://www.utas.edu.au/ data/assets/pdf_file/0006/302829/Non-TherapueticCirc_Final-Report-August-2012.pdf

68 Hellsten SK. Rationalising circumcision: from tradition to fashion, from public health to individual freedomcritical notes on cultural persistence of the practice of genital mutilation. J Med Ethics 2004;30:248-53.

69 Earp BD. Female Genital Mutilation (FGM) and male circumcision: should there be a separate ethical discourse? Practical Ethics 2014 (cited 24 Nov 2015). http://blog.practicalethics.ox.ac.uk/2014/ 02/female-genital-mutilation-and-male-circumcisiontime-to-confront-the-double-standard/ 